\title{
STUDI AWAL RENCANA LOKASI PELABUHAN DI PERAIRAN TELUK PRIGI KABUPATEN TRENGGALEK
}

\author{
Amiruddin Akbar Fisu') ) \\ 1) Universitas Andi Djemma, Palopo \\ 1) amiruddinakbarfisu07@gmail.com
}

\begin{abstract}
Abstrak
Pada perencanaan pelabuhan yang baik adalah yang lokasinya secara sistem jaringan mampu berperan dalam melancarkan pergerakan sistem transportasi secara keseluruhan, dengan demikian perencanaan dan pengembangannya perlu ditata dalam satu kesatuan sistem yang terpadu. Oleh karena itu penelitian ini bertujuan untuk mengidentifikasi awal lokasi perencanaan Pelabuhan Trenggalek, Jawa Timur secara makro. Letak pelabuhan sangat berperan, terutama dalam kaitannya dengan peran perekonomian. Aspek-aspek yang ditinjau antara lain aspek kewilayahan, baik pada rencana wilayah hinterland maupun wilayah di Kabupaten Trenggalek itu sendiri, aspek perekonomian wilayah, kinerja pelabuhan-pelabuhan terdekat, komponen rawan bencana, dan aspek lingkungan. Kemudian dilakukan pembobotan terhadap alternate-alternatif lokasi yang telah ditentukan berdasarkan kriteria-kriteria tersebut.
\end{abstract}

Kata kunci: Transportasi, Pemilihan lokasi, Pelabuhan, Prigi, Trenggalek

\section{PENDAHULUAN}

Pembangunan pelabuhan dilaksanakan sebagai pengembangan dari fasilitas yang sudah ada untuk mendukung perkembangan ekonomi setempat, maupun pada lokasi yang baru untuk membuka jalan bagi kegiatan transportasi warga sehari-hari yang bersifat mendasar. Oleh karena itu, pembangunan pelabuhan di Indonesia dalam lingkup Sub Sektor Perhubungan Laut akan terus dilaksanakan dalam rangka menunjang transportasi penumpang, petikemas, general cargo, dan barang curah (bulk), dalam skema pelayaran yang bersifat komersial maupun pelayaran perintis, pelayaran lokal ataupun pelayaran rakyat.

Dalam rangka menunjang kegiatan pembangunan pelabuhan, diperlukan sebuah aktvitas studi yang mampu memberikan gambaran secara lebih komprehensif tentang kelayakan pada beberapa aspek yang dianggap penting sebelum dimulainya pembangunan pelabuhan tersebut. Potensi pembangunan pelabuhan di Kabupaten Trenggalek merupakan bagian dari pengembangan koridor Yogyakarta-PrigiBlitar-Malang, salah satu dari 35 wilayah pengembangan strategis (WPS) yang pemerintah dengan mengadopsi Master Plan Percepatan dan Perluasan Pembangunan Ekonomi Indonesia (MP3EI). Bedanya, WPS memasukkan pesisir selatan sebagai wilayah pengembangan. Saat ini, di selatan Jawa hanya terdapat Pelabuhan Teluk Intan di Cilacap, Jawa Tengah yang captive hanya untuk pengapalan BBM alias bukan jalur logistik. Oleh sebab itu, jika Pelabuhan di Kabupaten Trenggalek dibangun akan menjadi pintu gerbang logistik di wilayah selatan Pulau Jawa.

Wilayah Selatan Jawa Timur mempunyai potensi ekonomi yang cukup besar dimana untuk distribusinya membutuhkan sarana dan prasarana transportasi yang murah dan efisien terutama untuk menunjang proses pemasaran hasil-hasil produk komoditi ke berbagai wilayah (antarpulau) maupun antarnegara. Dengan demikian pengembangan transportasi laut di wilayah pesisir laut selatan Jawa Timur menjadi kebutuhan yang sangat mendesak guna mengimbangi perkembangan kegiatan ekonomi di wilayah Jawa Timur bagian Utara.

Lokasi Pelabuhan Trenggalek secara tradicional cukup strategis, demikian juga secara geografis, sehingga potensi pengembangannya di masa mendatang diharapkan akan terjadi signifikan. Dukungan infrastrukstur berupa prasarana bangunan pelabuhan yang memadai akan lebih memacu pertumbuhan ekonomi. Sesuai Program Pemerintah Provinsi Jawa Timur untuk mengusahakan alternatif pengembangan moda transpotasi laut melalui pelayaran Short shipping yang membentang dari Pelabuhan Tanjung Perak sebagi pelabuhan pengumpul sampai Pelabuhan Pacitan di wilayah Selatan, maka untuk mendorong semakin cepatnya perkembangan transportasi laut di wilayah Jawa timur bagian selatan, telah dilakukan pengembangan Jalur Lintas Selatan (JLS) mulai dari wilayah Kabupaten Pacitan sampai dengan wilayah Kabupaten Banyuwangi untuk bagian wilayah Jawa Timur. JLS ini berfungsi untuk membuka dan mempermudah distribusi pemasaran komoditi di wilayah Selatan Jawa Timur, 
sehingga lebih memeratakan percepatan pembangunan antara wilayah Utara dan Selatan Jawa Timur.

Salah satu penjabaran dari program pengembangan transportasi laut di wilayah selatan Jawa Timur tersebut, pemerintah Provinsi jawa Timur melalui Dinas Perhubungan dan LLAJ mengadakan kegiatan studi Identifikasi Teknis Pengembangan/Pembangunan Pelabuhan Laut di Kabupaten Trenggalek.

Pada perencanaan pelabuhan yang baik adalah yang lokasinya secara sistem jaringan mampu berperan dalam melancarkan pergerakan sistem transportasi secara keseluruhan, dengan demikian perencanaan dan pengembangannya perlu ditata dalam satu kesatuan sistem yang terpadu. Menurut Fisu (2016), salah satu ciri kota atau zona yang dapat mempengaruhi pemilihan moda transportasi adalah kepadatan penduduk dan jarak dari pusat kota. Hal ini didukung oleh Natsir (2016) yang menyatakan ruang yang harus disediakan oleh kota untuk dijadikan prasarana transportasi dapat mempengaruhi pemilihan moda transportasi. Oleh karena itu penelitian ini bertujuan untuk mengidentifikasi awal lokasi perencanaan Pelabuhan Trenggalek, Jawa Timur secara makro. Letak pelabuhan sangat berperan, terutama dalam kaitannya dengan peran perekonomian.

\section{METODE}

Jenis penelitian ini adalah penelitian deskriptif-evaluatif, dengan pendekatan kualitatif. Penelitian deskriptif dapat diartikan sebagai proses pemecahan masalah yang dianalisa dengan menggambarkan keadaan obyek penelitian pada saat ini berdasarkan fakta-fakta yang nampak atau kondisi eksisting (Fisu, 2016). Pelaksanaan metode penelitian deskriptif tidak terbatas sampai pada pengumpulan dan penyusunan data, tetapi meliputi analisis untuk mengetahui penyebab permasalahan (Fisu, 2018). Metode ini yang kemudian akan digunakan untuk mengetahui dan mengidentifikasi lokasi yang layak dipertimbangkan sebagai lokasi pelabuhan dengan melihat aspek-aspek makro spasial sebagai parameter awal dalam penentuan lokasi pelabuhan Prigi, Trenggalek. Setelah itu dilakukan pembobotan pada masing-masing kriteria di tiap lokasi alternative yang telah ditentukan.

\section{HASIL DAN PEMBAHASIAN}

\section{Identifikasi Karakteristik Lokasi Rencana Pelabuhan}

Transportasi sangat terkait dengan aksesibilitas, dimana aksesibilitas merupakan faktor yang sangat menentukan organisasi ruang di kawasan perkotaan. Peningkatan aksesibilitas dan penggunaan lahan adalah proses yang saling terkait (Fisu, 2019). Rencana lokasi Pelabuhan di Kabupaten Trenggalek berada di Teluk Prigi yang berlokasi di pesisir selatan Pulau Jawa, dan berhadapan langsung dengan Samudera Hindia, tepatnya berada Kecamatan Watulimo, sekitar $48 \mathrm{~km}$ ke arah selatan Kota Trenggalek, Kabupaten Trenggalek. Kawasan ini memiliki banyak potensi, terutama potensi perikanan dan pariwisata.

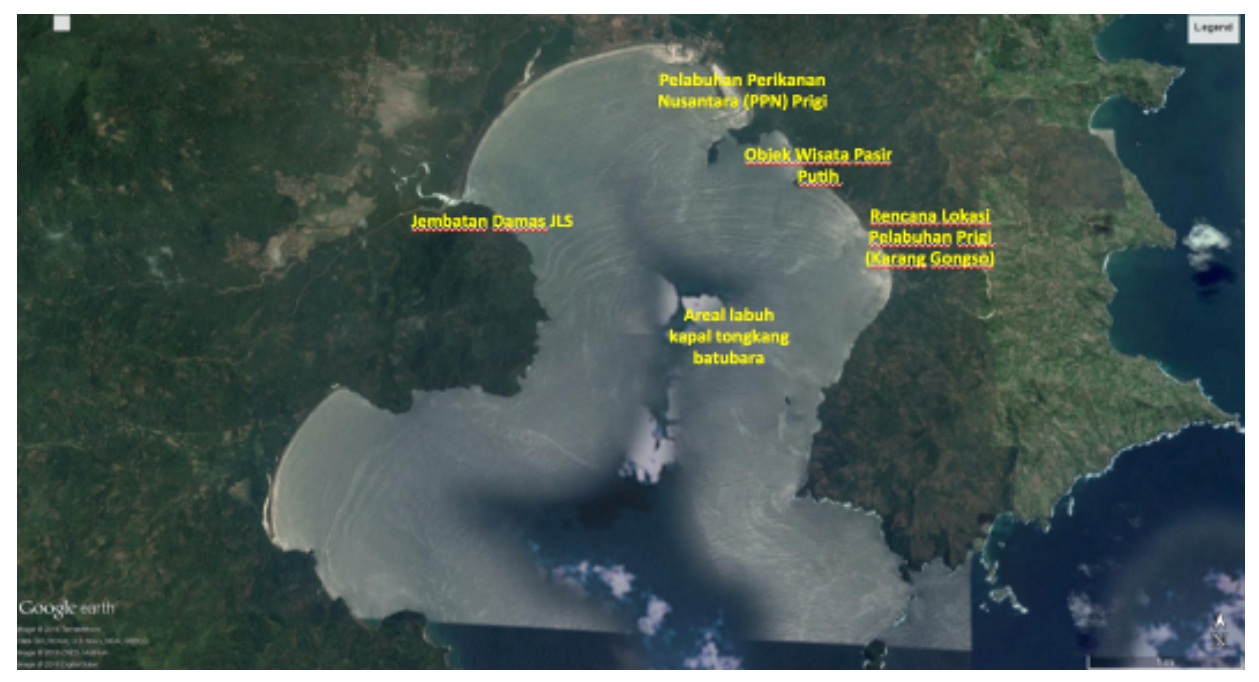

Gambar 1 Foto Udara Teluk Prigi

Teluk Prigi telah ditetapkan sebagai pusat industri perikanan. Hal ini merupakan langkah yang strategis untuk perkembangan ekonomi di Kecamatan Watulimo khususnya dan Kabupaten Trenggalek pada umumnya, karena telah mendapat dukungan baik dari pemerintah Provinsi Jawa Timur maupun 
dari pemerintah pusat. Terbukti dengan dibangunnya Pelabuhan Perikanan Nusantara Prigi, yang pengelolaannya dilakukan oleh Perum Prasarana Perikanan Samudera Cabang Prigi. Pelabuhan Perikanan Nusantara Prigi sebagai pusat pendaratan ikan yang berada di pantai selatan Jawa Timur dengan potensi perikanan laut yang sedemikian besar menjadi daya tarik tersendiri bagi pengusaha perikanan khususnya pengusaha penangkapan ikan. Melihat kondisi dan perkembangan industry perikanan yang menjanjikan tersebut, saat ini telah banyak pengusaha penangkapan ikan yang berasal dari Kalimantan, Sulawesi, dan pesisir pantai utara Pulau Jawa yang mengalihkan usahanya ke Pelabuhan Perikanan Prigi.

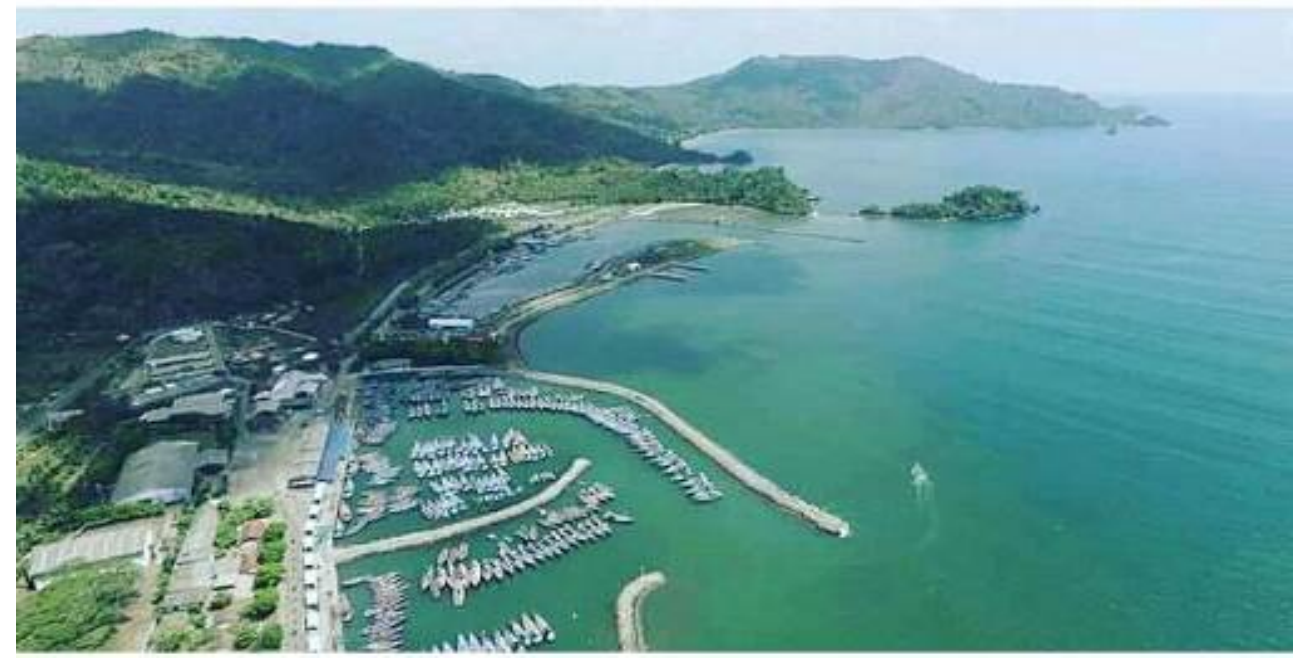

\section{Gambar 2. Pelabuhan Perikanan Nusantara Prigi}

Selain potensi perikanan, kawasan Teluk Prigi juga memiliki salah satu obyek wisata pantai yang ada di Kecamatan Watulimo, lokasinya berada di Desa Karanggongso dan termasuk dalam Ibukota Kecamatan Watulimo. Kondisi fisik kawasan wisata Pantai Prigi cukup datar 0-2\%, dengan ketinggian 0-25 mdpl. Kawasan ini sekarang dimanfaatkan sebagian untuk pengembangan pelabuhan, TPI (Tempat Pelelengan Ikan), Permukiman (depan hotel), kebun kelapa, perdagangan jasa (hotel, toko, warung, wartel), pangkalan kendaraan umum, menumen dan fasilitas umum.

Kawasan Wisata Prigi didukung oleh sistem jalan koridor yang mempunyai pemandangan pegunungan yang cukup menarik. Pengelolaan wisata di Pantai Prigi merupakan bagian dari tanggung jawab Pemerintah Kabupaten Trenggalek dan Dinas Pariwisata Kabupaten Trenggalek melalui Peraturan Daerah No.11 th. 1996, namun dengan adanya UU. No.22 tahun 1999 tentang Pemerintahan Daerah didalamnya mengatur otonomi daerah, Dinas Pariwisata, Lingkungan Hidup, Pertambangan dan Energi (Perlingtaben). Fungsi dan tugas Dinas Pariwisata adalah sebagai unsur pelaksana pemerintahan daerah dalam arti membantu Bupati dalam melaksanakan urusan rumah tangga di bidang kepariwisataan.

Lokasi perencanaan Pelabuhan Prigi terletak di Kecamatan Walutimo, Desa Karanggongso sebelah timur dari objek wisata Pantai Pasir Putih. Kegiatan pembangunan dan pengembangan infrastruktur perlu pengkajian mendalam dari berbagai sisi, termasuk aspek daya dukung lahan dan aspek tata ruang (Fisu, 2019). Di sisi lain pertumbuhan aktivitas ekonomi akan mempengaruhi permintaan terhadap transportasi yang lebih banyak (Fisu, 2019), pembangunan atau pengembangan sarana transportasi juga dapat menimbulkan dampak positif terhadap suatu wilayah (Fisu, 2018). Kegiatan transportasi harus dilakukan secara menyeluruh dengan keterpaduan fisik antar moda berupa titik simpul pertemuan antar moda (Humang, 2016).

Aksesibilitas menuju lokasi perencanaan pelabuhan ini cukup baik dengan jalan beraspal. Kondisi perairan pada lokasi ini juga cukup tenang dibandingkan dengan sisi barat atau utara Teluk Prigi. Hal ini dikarenakan lokasi ini tidak berhadapan langsung dengan pintu atau ambang luar dari Teluk Prigi yang berhadapan langsung dengan Samudera Hindia. Lokasi berada tidak jauh dari jalan raya beraspal. Kondisi pada sisi darat merupakan lahan kosong yang ditumbuhi semak dan beberapa pohon kelapa.

Pembangunan Jalan Lintas Selatan (JLS) di Kabupaten Trenggalek adalah salah satu upaya pemerintah untuk memberikan kemudahan akses transportasi masyarakat untuk menjangkau sentrasentra pelayanan baik pendidikan, kesehatan, termasuk infrastruktur pelabuhan. Realisasi fisik Jalan Lintas Selatan di Kabupaten Trenggalek hingga tahun 2016 telah ditangani hingga 24,024 km (29,48\%) 
untuk jalan dan 71,37\% (399 m/ 10 buah) jembatan dari total perencanaan 81,475 km. Pelaksanaan pembangunan jalan yang direncanakan sepanjang $81,475 \mathrm{~km}$ dengan $559 \mathrm{~m}$ berupa jembatan penghubung. Rencana pembangunan pelabuhan di Teluk Prigi Kabupaten Trenggalek, telah ditunjang dengan kebijakan pembangunan Jalur Lintas Selatan (JLS). Arahan pengembangan JLS yang akan menghubungkan dengan pusat-pusat pelayanan di masing-masing wilayah. Jalur JLS di Kabupaten Trenggalek berupa ruas Batas Pacitan - Panggul - Craken - Munjungan - Prigi - Karanggongso - Batas T. Agung.

Tabel 1 Realisasi Fisik JLS di Kabupaten Trenggalek Hingga Tahun 2016

\begin{tabular}{|c|l|r|r|c|}
\hline NO & \multicolumn{1}{|c|}{ NAMA RUAS } & $\begin{array}{c}\text { PANJANG } \\
\text { RUAS }(\mathbf{k m})\end{array}$ & \multicolumn{1}{c|}{$\begin{array}{c}\text { SUDAH } \\
\text { DITANGANI } \\
(\mathbf{k m})\end{array}$} & KET. \\
\hline 1 & Bts. Pacitan - Panggul & 8.1 & 8.1 & Sudah teraspal $8.1 \mathrm{~km}$ \\
\hline 2 & Panggul - Craken & 30.862 & 5.0 & Teraspal $3.6 \mathrm{~km}$ \\
\hline 3 & Craken - Munjungan & 5.703 & 1.46 & Teraspal $1.46 \mathrm{~km}$ \\
\hline 4 & Munjungan - Prigi & 21.779 & 6.54 & Teraspal $6.54 \mathrm{~km}$ \\
\hline 5 & Prigi - Karanggongso & 11.111 & 2.924 & Teraspal $2.924 \mathrm{~km}$ \\
\hline 6 & $\begin{array}{l}\text { Karanggongso - Bts. Tulung } \\
\text { Agung }\end{array}$ & 3.92 & 0 & Belum bebas \\
\hline & JUMLAH & $\mathbf{8 1 . 4 7 5}$ & $\mathbf{2 4 . 0 2 4}$ & \\
\hline
\end{tabular}

Sumber: Dinas PU Jawa Timur

Selain itu, akses menuju Pelabuhan Prigi juga dapat ditempuh melalui jalur jalan kolektor yang sudah ada antara Durenan - Watulimo - Prigi, yang dapat diusulkan untuk ditingkatkan kapasitasnya. Kondisi jalan dari Kota Trenggalek menuju rencana lokasi pelabuhan di Teluk Prigi cukup baik, bermaterialkan aspal dengan jarak kurang lebih $48 \mathrm{~km}$ ditempuh dalam waktu sekitar satu jam. Kondisi jalan berbukit dan berkelok-kelok sehingga cukup berbahaya jika perjalanan dilakukan dengan kecepatan tinggi.

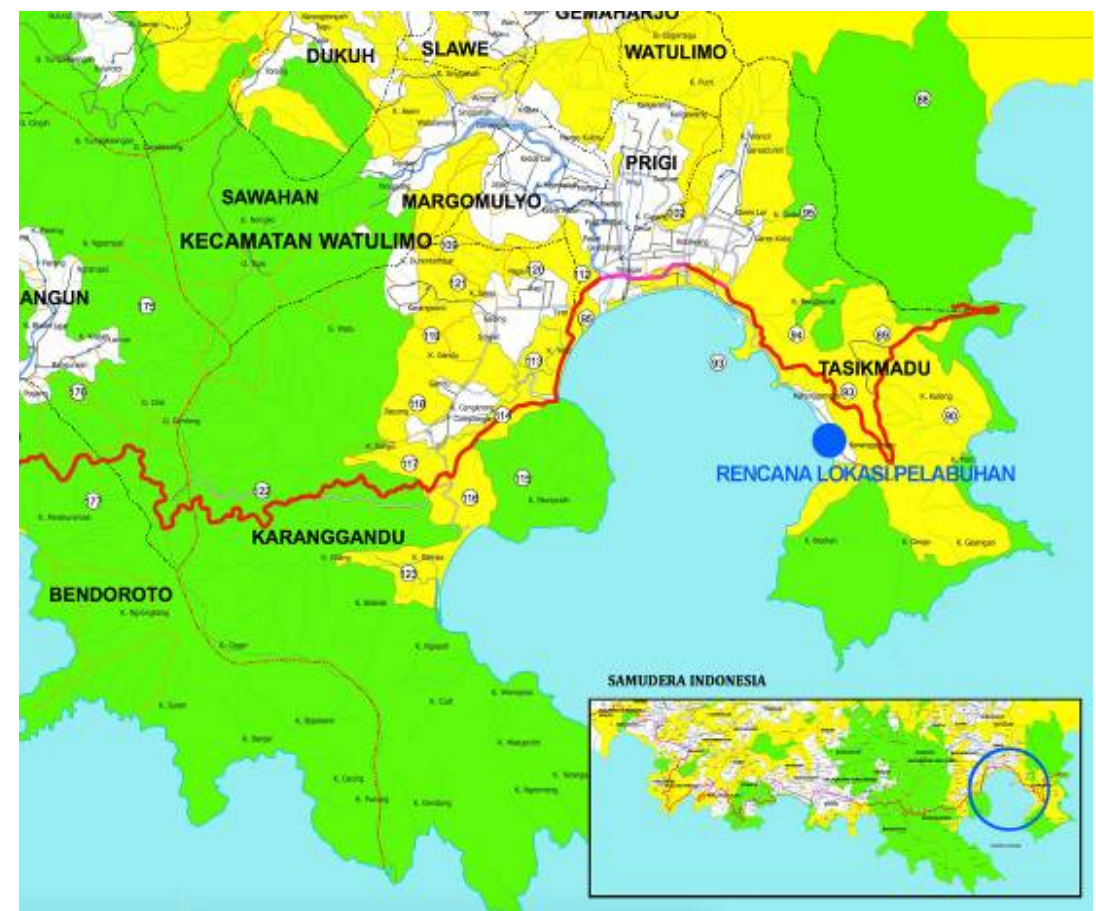

Gambar 3. Akses Jalan Lintas Selatan Menuju Rencana Pelabuhan di Teluk Prigi 
Kondisi status lahan di sekitar rencana pelabuhan berada di tepi pantai yang berdekatan dengan daerah pemukiman dan tanah Perhutani. Untuk lokasi rencana pelabuhan sendiri, berdasarkan hasil FGD bersama BPN dan Bupati Trenggalek, diidentifikasi bahwa lokasi rencana pelabuhan pada saat ini adalah milik Perhutani, dan saat ini sedang dalam proses administrasi tukar guling dengan lahan milik Pemerintah Kabupaten Trenggalek dalam rangka pembebasan lahan untuk kepentingan perencanaan pembangunan pelabuhan

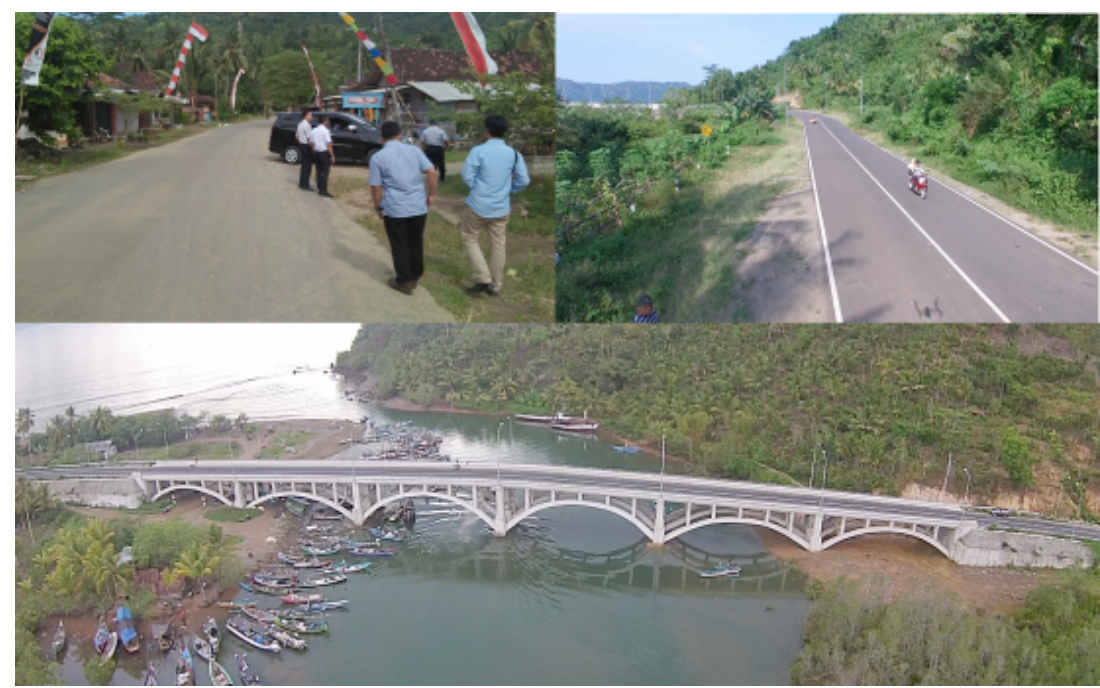

Gambar 4 Kondisi Prasarana Jalan di sekitar Teluk Prigi

Berdasarkan peta bathimteri hasil studi Identifikasi Teknis Pengembangan/ Pembangunan Pelabuhan Laut di Kabupaten Trenggalek yang dilakukan Dinas Perhubungan Provinsi Jawa Timur tahun 2011, kedalaman perairan di sekitar lokasi pelabuhan Prigi sekitar 10 meter sampai dengan -15 meter LWS. Kedalaman -10 meter dicapai pada jarak antara 130-150 meter dari garis pantai. Sedangkan kondisi di mulut teluk sekitar 40-60 meter LWS berdasarkan hasil wawancara dengan nelayan dan penyedia jasa kapal pariwisata di teluk Prigi. Berdasarkan peta bathimteri hasil studi Identifikasi Teknis Pengembangan / Pembangunan Pelabuhan Laut di Kabupaten Trenggalek yang dilakukan Dinas Perhubungan Provinsi Jawa Timur tahun 2011, tipe pasang surut di Perairan Prigi Kabupaten Trenggalek Jawa Timur adalah pasang surut harian ganda. Sedangkan untuk kondisi arus, dijelaskan sebagai berikut : Lokasi CM1, secara umum menunjukkan arah dominan timurlaut - selatan dengan kecepatan arus pasang surut maksimum $0.24 \mathrm{~m} / \mathrm{dt}$.. Lokasi CM2, secara umum menunjukkan arah dominan baratlaut - tenggara dengan kecepatan arus pasang surut maksimum $0.19 \mathrm{~m} / \mathrm{dt}$. Kondisi Spring Tide. Lokasi CM1, secara umum menunjukkan arah dominan timurlaut-baratdaya dengan kecepatan arus pasang surut maksimum $0.41 \mathrm{~m} / \mathrm{dt}$. Lokasi $\mathrm{CM} 2$, secara umum menunjukkan arah dominan timurlaut-baratdaya dengan kecepatan arus pasang surut maksimum $0.29 \mathrm{~m} / \mathrm{dt}$.

Kabupaten Trenggalek sebagian besar bertopografi terjal lebih dari $40 \%$ seluas \pm 28.378 ha yang merupakan daerah rawan bencana longsor. Sebagian besar lahan ini merupakan lahan kritis yang rentan mengalami gerakan tanah. Kawasan ini tersebar di beberapa kecamatan diantaranya Kecamatan Bendungan, Pule, Dongko, Watulimo, Munjungan dan Kecamatan Panggul. Luas dataran rendah dengan tingkat kemiringan antara $0-15 \%$ adalah \pm 42.291 ha.

Kawasan yang bertopografi datar sebagian besar terletak di Kabupaten Trenggalek bagian utara meliputi Kecamatan Trenggalek, Karangan, Pogalan, Durenan, dan Tugu. Dengan terbatasnya kawasan datar di Kabupaten Trenggalek, maka arah pembangunan terpusat di kawasan tersebut sehingga diperlukan rekayasa teknologi yang tepat serta berwawasan lingkungan jika pengembangan kawasan dilakukan di kawasan terjal. Selengkapnya mengenai tingkat kelerengan pada Kabupaten Trenggalek dapat dilihat pada table di bawah ini: 
Tabel 2: Tingkat Kelerengan kabupaten Trenggalek

\begin{tabular}{|c|c|c|c|c|}
\hline No & Tingkat Kelerengan & Klasifikasi & Luas (Ha) & $\%$ \\
\hline 1 & $0-2 \%$ & Datar & $24.529,76$ & 19,68 \\
2 & $2-15 \%$ & Datar & $17.761,62$ & 14,25 \\
3 & $15-25 \%$ & $\begin{array}{c}\text { Bukit/Perbukitan } \\
\text { Gunung/Pegunungan dan }\end{array}$ & $21.926,23$ & 17,59 \\
4 & $25-40 \%$ & $\begin{array}{c}\text { Bukit/Perbukitan } \\
\text { Gunung/Pegunungan dan }\end{array}$ & $32.076,13$ & 25,73 \\
5 & $>40 \%$ & Bukit/Perbukitan & $28.378,11$ & 22,76 \\
\hline
\end{tabular}

Sumber: RTRW Kab. Trenggalek

Untuk kondisi topografi pada wilayah rencana pembangunan pelabuhan dan sekitarnya cenderung datar dan memiliki ketinggian 0-5 meter si atas permukaan laut serta memiliki kemiringan 0$5 \%$ sehingga memiliki lahan yang datar dan dapat digunakan untuk membangun fasilitas pelabuhan. Meskipun semakin ke utara maka keadaan topografi semakin berbukit, namun mengingat skala pelayanan Pelabuhan Prigi direncanakan hanya \menghubungkan ke luar wilayah serta grid untuk pergerakan di dalam kota. Pola pergerakan di Kabupaten Trenggalek terdiri dari pergerakan orang dan pergerakan barang. Pola pergerakan orang berupa pergerakan lokal yang didominasi oleh kegiatan kegiatan perdagangan dan jasa, pendidikan, perkantoran, serta pariwisata yang tersebar di seluruh Kabupaten Trenggalek. Intensitas pergerakan manusia terjadi pada pagi hari mulai pukul 06.00-09.00 berangkat dari rumah menuju pusat-pusat kegiatan. Pergerakan manusia yang terjadi pada siang hari yaitu pada pukul 12.00-14.00. Pada jam tersebut didominasi oleh pergerakan pendidikan dan perkantoran, dimana jam tersebut merupakan jam pulang sekolah dan jam istirahat bagi pekerja kantor.

Pola pergerakan regional di Kabupaten Trenggalek didominasi oleh pergerakan barang. Pola tersebut menghubungkan Kabupaten Trenggalek dengan Kabupaten Tulungagung, Trenggalek Ponorogo, dan Trenggalek - Pacitan. Moda transportasi yang digunakan antara lain truk, pick up, dan mobil box. Pergerakan barang lebih sering terjadi pada siang sampai malam hari sehingga tidak mengganggu lalu-lintas kota. Pola pergerakan di Kabupaten Trenggalek diilustrasikan pada gambar di bawah ini:

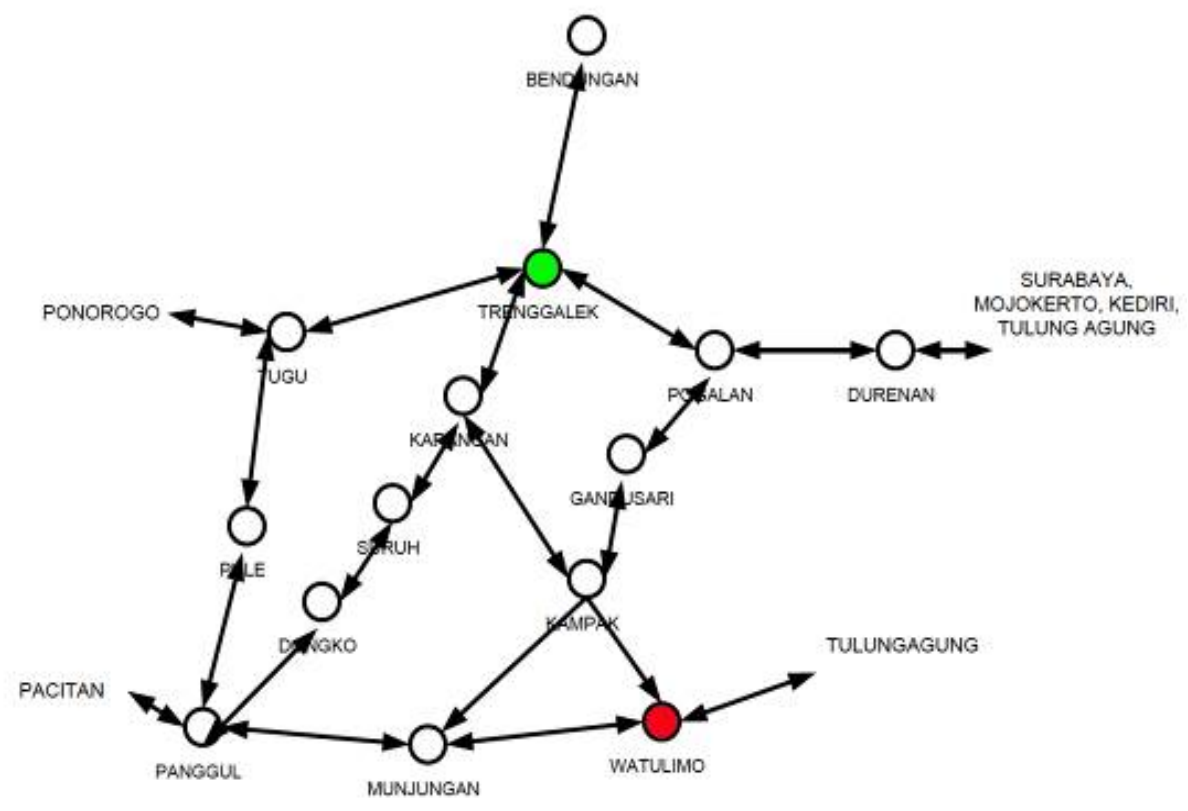

Gambar 5: Pola Pergerakan di Kabupaten Trenggalek 


\section{Analisis Ekonomi Wilayah \\ Penentuan Wilayah Hinterland}

Sebelum melakukan analisis potensi wilayah hinterland, perlu ditentukan terlebih dulu batasan atau delineasi wilayah hinterland masing-masing lokasi rencana pelabuhan. Dasar penentuan wilayah hinterland antara lain : Identifikasi wilayah hinterland pelabuhan eksisting, Ketersediaan jaringan jalan ke pelabuhan dari wilayah hinterland, Kondisi topografi dan geografi wilayah, dan Rencana Pembangunan Daerah.Rencana wilayah hinterland Pelabuhan Prigi didasarkan pada jarak dari masingmasing pusat kabupaten/kota yang bersangkutan dengan lokasi Pelabuhan Prigi di Kabupaten Trenggalek.Kemudian jarak tersebut dibandingkan dengan jarak antara Pelabuhan Tanjung PerakSurabaya dengan masing-masing pusat kabupaten/kota tersebut. Apabila jarak antara kota yang bersangkutan lebih dekat dengan Pelabuhan Prigi dibandingkan dengan Pelabuhan Tanjung Perak, maka daerah tersebut dimasukkan dalam cakupan wilayah pelayanan Pelabuhan Prigi. Berdasarkan indikator tersebut ,maka terdapat 11 kabupaten/kota di Provinsi Jawa Timur yang masuk dalam cakupan wilayah pelayanan pelabuhan laut Prigi-Trenggalek.

Tabel 3. Kabupaten / Kota yang berpotensi menjadi Layanan Pelabuhan Laut Prigi dan Jaraknya Terhadap Kabupaten Trenggalek

\begin{tabular}{|c|l|c|}
\hline No & \multicolumn{1}{|c|}{ Wilayah Hinterland } & $\begin{array}{c}\text { Jarak ke Rencana } \\
\text { Pelabuhan Prigi }\end{array}$ \\
\hline 1 & Kabupaten Madiun & 82 \\
\hline 2 & Kabupaten Magetan & 106 \\
\hline 3 & Kabupaten Ponorogo & 52 \\
\hline 4 & Kabupaten Kediri & 63 \\
\hline 5 & Kabupaten Nganjuk & 90 \\
\hline 6 & Kabupaten Tulungagung & 32 \\
\hline 7 & Kabupaten Blitar & 64 \\
\hline 8 & Kabupaten Trenggalek & 0 \\
\hline 9 & Kota Kediri & 63 \\
\hline 10 & Kota Blitar & 64 \\
\hline 11 & Kota Madiun & 82 \\
\hline
\end{tabular}

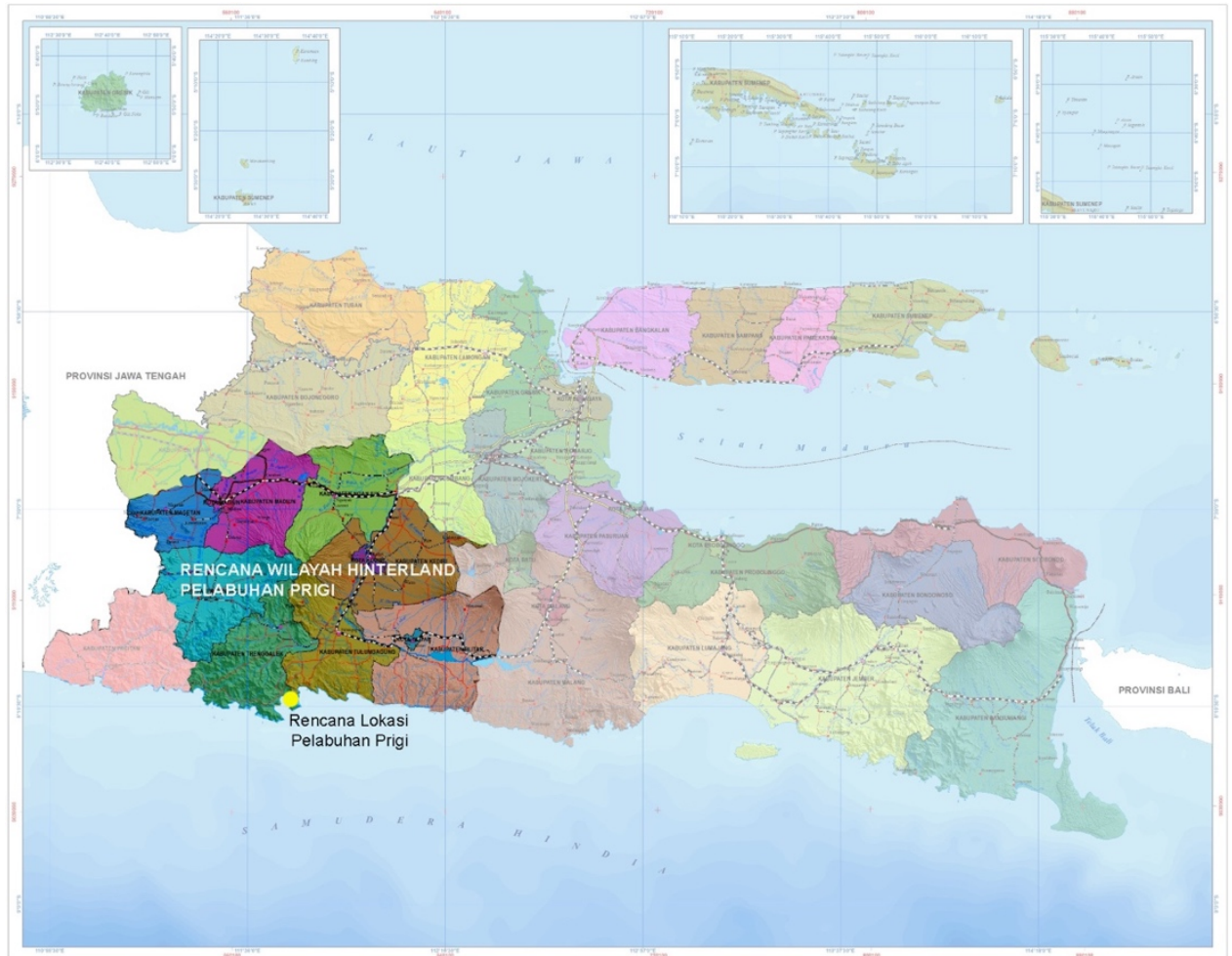

Gambar 6. Rencana Wilayah Hinterland Pelabuhan Prigi 


\section{Klasifikasi Sektor Berdasarkan Tingkat Pertumbuhan}

Berdasarkan hasil penilaian wilayah kabupaten/kota menggunakan Tipologi Klassen, kemudian dilakukan penilaian terhadap lokasi studi yang dibagi menjadi tiga kelompok. Ketiga kelompok tersebut memiliki indikator yang berbeda. Pembagian kelompok indikator tersebut dapat dilihat pada tabel berikut.

Tabel 4. Identifikasi Lokasi Hinterland Pelabuhan Berdasarkan Variabel Pertumbuhan Wilayah Hinterland

\begin{tabular}{|l|r|r|l|c|}
\hline \multicolumn{1}{|c|}{ Kabupaten/Kota } & y & r & \multicolumn{1}{c|}{ Klasifikasi Tipologi } & Kuadran \\
\hline Kabupaten Madiun & $12,566.7$ & 0.08 & Daerah Sedang Tumbuh & II \\
\hline Kabupaten Magetan & $12,584.5$ & 0.05 & Daerah Relatif Tertinggal & IV \\
\hline Kabupaten Ponorogo & $13,486.7$ & 0.23 & Daerah Sedang Tumbuh & II \\
\hline Kabupaten Kediri & $27,780.1$ & 0.03 & Daerah Tertekan & III \\
\hline Kabupaten Nganjuk & $17,332.6$ & 0.16 & Daerah Sedang Tumbuh & II \\
\hline Kabupaten Tulungagung & $25,817.1$ & 0.04 & Daerah Tertekan & III \\
\hline Kabupaten Blitar & $25,317.0$ & -0.35 & Daerah Tumbuh cepat & I \\
\hline Kabupaten Trenggalek & $12,312.8$ & 0.03 & Daerah Relatif Tertinggal & IV \\
\hline Kota Kediri & $88,335.8$ & 0.24 & Daerah Tumbuh cepat & I \\
\hline Kota Blitar & $4,367.6$ & 0.10 & Daerah Sedang Tumbuh & II \\
\hline Kota Madiun & $9,265.4$ & 0.19 & Daerah Sedang Tumbuh & II \\
\hline
\end{tabular}

Berdasarkan tabel di atas, pertumbuhan wilayah di lokasi hinterland pelabuhan usulan di Kabupaten Trenggalek tergolong bervariasi. Pertumbuhan wilayah di wilayah hinterland rencana pelabuhan ini ada pada setiap kuadran. dua Kabupaten/kota pada kuadran I, lima kabupaten/ kota pada kuadran II, dua kabupaten/ kota pada kuadran III dan dua kabupaten/ kota pada kuadran IV. Dari seluruh kabupaten/ kota wilayah hinterland,yang memiliki nilai rerata PDRB terbesar atau nilai (y) berada pada Kota Kediri. Untuk yang memiliki nilai (y) terendah berada pada Kota Blitar.

Untuk Memudahkan pembobotan dalam analisis Pertumbuhan wilayah dilakukan skoring dengan kriteria sebagai berikut :

Tabel 5. Pembobotan Wilayah hinterland Rencana Lokasi Pelabuhan Berdasarkan Aspek Pertumbuhan Wilayah

\begin{tabular}{|c|c|c|c|}
\hline No & Kabupaten/Kota & Skor & Ket. \\
\hline 1 & Kabupaten Madiun & 6 & sedang \\
\hline 2 & Kabupaten Magetan & 6 & sedang \\
\hline 3 & Kabupaten Ponorogo & 6 & sedang \\
\hline 4 & Kabupaten Kediri & 10 & tinggi \\
\hline 5 & Kabupaten Nganjuk & 6 & sedang \\
\hline 6 & Kabupaten Tulungagung & 10 & tinggi \\
\hline 7 & Kabupaten Blitar & 10 & tinggi \\
\hline 8 & Kabupaten Trenggalek & 6 & sedang \\
\hline 9 & Kota Kediri & 10 & tinggi \\
\hline 10 & Kota Blitar & 2 & rendah \\
\hline 11 & Kota Madiun & 2 & rendah \\
\hline
\end{tabular}

Berdasarkan analisis pertumbuhan wilayah pada wilayah hinterland diketahui bahwa Kabupaten Trenggalek Selor di mana terdapat rencana lokasi pelabuhan Prigi memiliki pertumbuhan wilayah yang sedang, hal ini dikarenakan PDRB Kabupaten Trenggalek yang tidak begitu tinggi jika dibandingkan 
dengan kabupaten/kota lainnya yang ada pada wilayah hinterland. Terdapat empat wilayah yang aspek pertumbuhan wilayahnya tinggi, yaitu Kabupaten Kediri, Kabupaten Tulungagung, Kabupaten Blitar dan Kota Kediri. Sedangkan wilayah yang aspek pertumbuhan wilayahnya rendah hanya ada dua wilayah, yaitu kota Blitar dan Kota Madiun. Hal ini menunjukkan bahwa secara keseluruhan,wilayah hinterland memiliki pertumbuhan wilayah yang cukup tinggi dan potensial untuk dikembangkan.

\section{Analisis Kesesuaian Tata Ruang}

Berdasarkan analisis kebijakan tata ruang yang telah dilakukan, maka penilaian aspek tata ruang terhadap rencana lokasi pelabuhan di kabupaten trenggalek sebagaimana disajikan pada tabel di bawah ini.

Tabel 6. 1 Penilaian Rencana Pelabuhan Berdasarkan Aspek Tata Ruang

\begin{tabular}{|l|l|c|l|c|}
\hline \multirow{2}{*}{$\begin{array}{c}\text { Sub Aspek } \\
\text { Penilaian }\end{array}$} & \multicolumn{2}{c|}{ Lokasi Prigi (Karanggongso) } & \multicolumn{2}{c|}{ Lokasi Prigi (Cangkrong) } \\
\cline { 2 - 5 } & \multicolumn{1}{|c|}{ Keterangan } & Nilai & \multicolumn{1}{c|}{ Keterangan } & Nilai \\
\hline Pola Ruang & $\begin{array}{l}\text { Rencana Pelabuhan Berada } \\
\text { pada kawasan Budidaya } \\
\text { Lainnya yaitu kawasan } \\
\text { hutan produksi }\end{array}$ & 5 & $\begin{array}{l}\text { Rencana Pelabuhan Berada } \\
\text { pada kawasan Budidaya } \\
\text { Lainnya yaitu kawasan } \\
\text { hutan produksi }\end{array}$ & 5 \\
\hline Struktur Ruang & $\begin{array}{l}\text { Rencana pelabuhan } \\
\text { tercantum dalam review } \\
\text { RIPN, RTRW Provinsi, } \\
\text { dan RTRW Kabupaten }\end{array}$ & 6 & $\begin{array}{l}\text { Rencana pelabuhan } \\
\text { tercantum dalam review } \\
\text { RIPN, RTRW Provinsi, } \\
\text { dan RTRW Kabupaten }\end{array}$ & 6 \\
\hline $\begin{array}{l}\text { Kawasan } \\
\text { Strategis }\end{array}$ & $\begin{array}{l}\text { Berada pada kawasan } \\
\text { strategis provinsi dan } \\
\text { kabupaten }\end{array}$ & 6 & $\begin{array}{l}\text { Berada pada kawasan } \\
\text { strategis provinsi dan } \\
\text { kabupaten }\end{array}$ & 6 \\
\hline
\end{tabular}

\section{Analisis Kinerja Pelabuhan Eksisting di Sekitar Lokasi Studi}

Pelabuhan eksisting terdekat dari wilayah perencanaan Pelabuhan Prigi berada di sebelah barat lokasi rencana pelabuhan. Namun status pelabuhan tersebut merupakan pelabuhan perikanan, sehingga skala pelayanan pelabuhan perikanan ini berbeda dengan skala pelayanan pelabuhan rencana meskipun secara fisik memiliki cakupan wilayah yang sama. Pelabuhan lain yang juga merupakan pelabuhan barang dan berada di selatan Pulau Jawa bagian timur adalah Pelabuhan Pacitan dan Pelabuhan Sendang Biru di Malang. Jika ditarik garis lurus dari lokasi rencana Pelabuhan Prigi ke lokasi Pelabuhan Pacitan memiliki jarak 40 mil, sedangkan untuk Pelabuhan Sendang Biru memiliki jarak sekitar 55 mil.

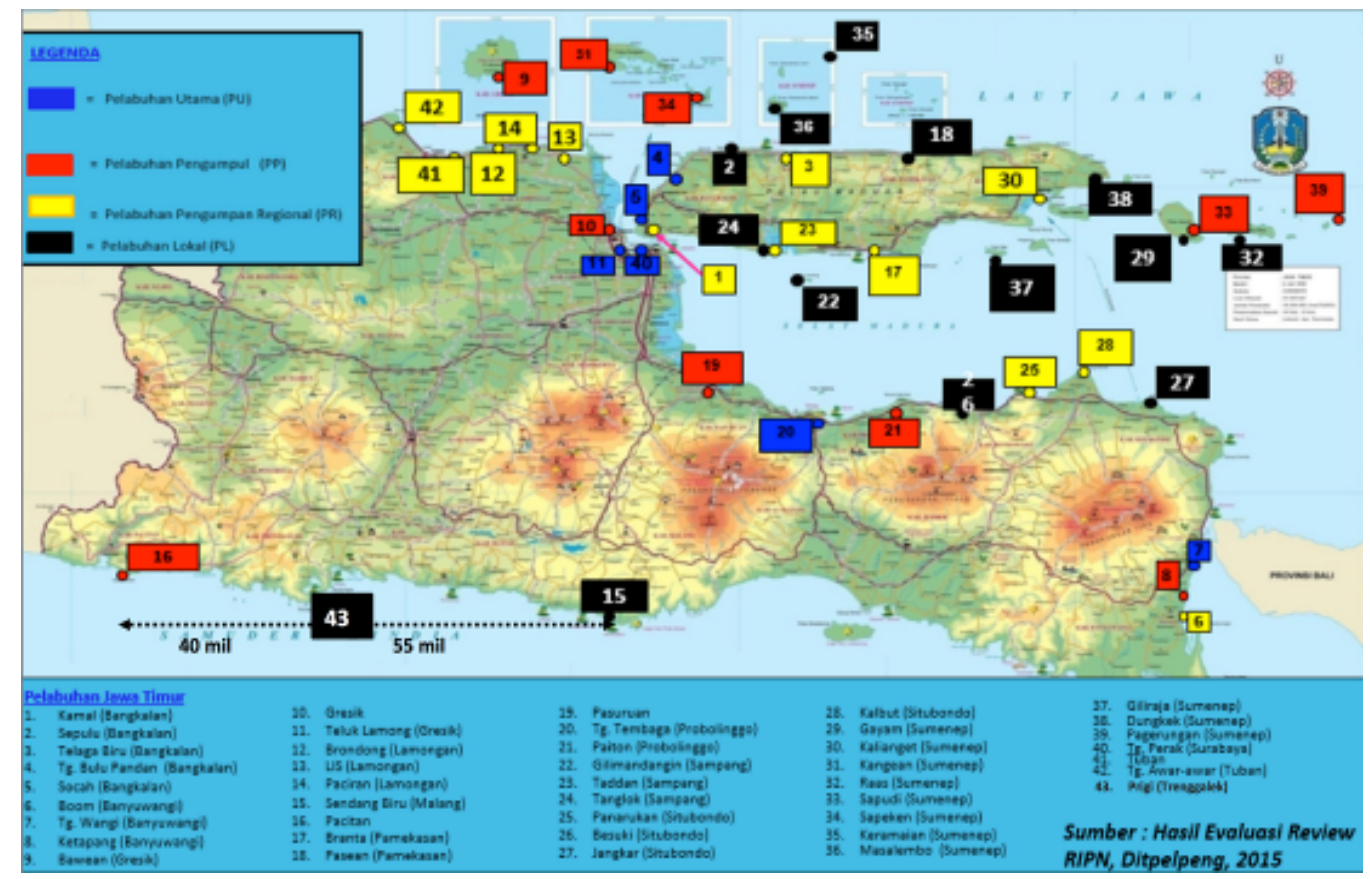

Gambar 11: Lokasi rencana Pelabuhan Prigi terhadap pelabuhan sekitar 
Pelabuhan Gelon Pacitan direncanakan sebagai pelabuhan barang dan niaga di Desa Kembang, Kecamatan Pacitan oleh Kementerian Perhubungan Republik Indonesia. Proyek tersebut rencananya menggunakan dana APBN sebesar Rp 45 miliar. Dan didukung APBD Provinsi Jatim Rp 23 miliar untuk membangun akses jalan menuju pelabuhan. Sedangkan pemkab kebagian jatah menyediakan lahan. Hingga saat ini Pelabuhan Gelon Pacitan masih dalam proses pembangunan. Sama halnya dengan pelabuhan Sendang Biru Malang yang bahkan masih dalam proses perencanaan dan studi kelayakan.

Berdasarkan hal tersebut, maka dapat dikatakan belum ada aktifitas pelabuhan di sekitar wilayah studi. Namun pada Kabupaten Pacitan, telah beroperasi Pelabuhan Terminal Khusus batubara untuk kepentingan PLTU milik PT. PLN (Persero), dan tentu saja Pelabuhan Perikanan Nasional Prigi yang juga terletak di Teluk Prigi, tepatnya sebelah Barat dari lokasi rencana pembangunan Pelabuhan Prigi.

\section{Analisis Rona Awal Lingkungan dan Rawan Bencana}

Analisis fisik kimia dilakukan untuk mengetahui faktor-faktor lingkungan alam yang dapat menghambat pembangunan fasilitas pelabuhan di wilayah studi atau dampak lingkungan yang tinggi jika dibangun pelabuhan di lokasi tersebut. Penilian fisik kimia didasarkan pada kondisi penggunaan lahan di kawasan daratan pelabuhan, sedangkan komponen biologi hayati didasarkan pada kondisi perairan atau kondisi dasar laut untuk kawasan perairan.

Tabel 6. Kriteria Penilaian Komponen Fisik Kimia dan Biologi-Hayati

\begin{tabular}{|l|l|l|l|}
\hline $\begin{array}{l}\text { Indikator Komponen Fisik } \\
\text { Kimia }\end{array}$ & $\begin{array}{l}\text { Indikator Komponen } \\
\text { Biologi Hayati }\end{array}$ & Keterangan Penilaian & Skor \\
\hline $\begin{array}{l}\text { Penggunaan lahan kawasan } \\
\text { daratan berupa kawasan } \\
\text { mangrove atau kawasan lindung } \\
\text { lainnya }\end{array}$ & $\begin{array}{l}\text { Kondisi dasar laut berupa } \\
\text { karang atau terumbu karang }\end{array}$ & Risiiko tinggi & 1 \\
\hline $\begin{array}{l}\text { Penggunaan lahan berupa } \\
\text { permukiman padat, hutan } \\
\text { produksi, atau perkebunan } \\
\text { produktif }\end{array}$ & $\begin{array}{l}\text { Kondisi perairan merupakan } \\
\text { daerah tangkapan ikan }\end{array}$ & Risiko Sedang & 2 \\
\hline $\begin{array}{l}\text { Penggunaan lahan berupa semak } \\
\text { belukar, rawa, atau lahan tidur }\end{array}$ & $\begin{array}{l}\text { Kondisi perairan bukan } \\
\text { karang dan bukan daerah } \\
\text { tangkapan ikan }\end{array}$ & Risiko rendah & 3 \\
\hline
\end{tabular}

Tabel 7. Analisis Penilaian Komponen Fisik Kimia\& Biologi Hayati

\begin{tabular}{|l|l|l|l|}
\hline Komponen & Kondisi & $\begin{array}{l}\text { Keterangan } \\
\text { Penilaian }\end{array}$ & Skor \\
\hline Fisik-kimia & $\begin{array}{l}\text { Penggunaan lahan kawasan daratan berupa } \\
\text { kawasan semak belukar, dan terdapat } \\
\text { beberapa pohon kelapa }\end{array}$ & Risiko rendah & 3 \\
\hline Biologi-Hayati & $\begin{array}{l}\text { Tidak terdapat karang pada wilayah } \\
\text { perairan. Namun masuk pada wilayah } \\
\text { tangkapan ikan PPN Prigi }\end{array}$ & Risiko sedang & 2 \\
\hline
\end{tabular}

Sumber : Hasil survey dan Analisis

Berdasarkan pemaparan lokasi rawan bencana yang telah dilakukana, secara umum dapat disimpulkan bahwa lokasi pelabuhan yang terletak di Kecamatan Watulimo masuk kawasan rawan longsor, dan tsunami. Namun diantara ketiga kecamatan yang berada di wilayah pesisir, perairan Prigi yang terletak di Kecamatan Watulimo ini merupakan perairan yang cenderung tenang dibandingkan dengan wilayah lainnya yang berada di Kabupaten Trenggalek. 
Tabel 8. Indikator Penilaian Komponen Rawan Bencana

\begin{tabular}{|l|l|l|}
\hline Indikator Komponen Rawan Bencana & Keterangan Penilaian & Skor \\
\hline Lokasi Pelabuhan berada pada lebih dari satu zona rawan bencana & Rendah & 1 \\
\hline Lokasi Pelabuhan berada pada tidak lebih dari satu zona rawan bencana & Sedang & 2 \\
\hline Lokasi Pelabuhan tidak berada pada zona rawan bencana & Tinggi & 4 \\
\hline
\end{tabular}

Tabel 9. Analisis Penilaian Komponen Rawan Bencana

\begin{tabular}{|l|l|l|}
\hline Komponen & Kondisi & $\begin{array}{l}\text { Keterangan } \\
\text { Penilaian }\end{array}$ \\
\hline Rawan Bencana & $\begin{array}{l}\text { Berada pada zona rawan bencana gerakan tanah longsor (kondisi } \\
\text { tanah labil) dan tsunami, tidak berada pada wilayah rawan banjir }\end{array}$ & sedang \\
\hline
\end{tabular}

Dikarenakan aspek lingkungan digabungkan menjadi satu aspek, maka perlu dilakukan penggabungan nilai masing-masing sub aspek mulai dari kondisi fisik kimia, biologi hayati, hingga kawasan rawan bencana dengan menggunakan metode rata-rata. Proses penilaian aspek lingkungan sebagaimana disajikan pada tabel di bawah ini.

Tabel 10. Penilaian Rencana Lokasi Pelabuhan Prigi berdasarkan Aspek Lingkungan

\begin{tabular}{|l|l|l|l|}
\hline Komponen & Kondisi & $\begin{array}{l}\text { Keterangan } \\
\text { Penilaian }\end{array}$ & Skor \\
\hline Fisik-kimia & $\begin{array}{l}\text { Penggunaan lahan kawasan daratan } \\
\text { berupa kawasan semak belukar, dan } \\
\text { terdapat beberapa pohon kelapa }\end{array}$ & Risiko rendah & 3 \\
\hline Biologi-Hayati & $\begin{array}{l}\text { Tidak terdapat karang pada wilayah } \\
\text { perairan. Namun masuk pada wilayah } \\
\text { tangkapan ikan PPN Prigi }\end{array}$ & Risiko sedang & 2 \\
\hline Rawan Bencana & $\begin{array}{l}\text { Berada pada zona rawan bencana gerakan } \\
\text { tanah longsor (kondisi tanah labil) dan } \\
\text { tsunami, tidak berada pada wilayah rawan } \\
\text { banjir }\end{array}$ & sedang & 2 \\
\hline Skor total & \multicolumn{2}{|l}{} \\
\hline
\end{tabular}

\section{Indikasi Kelayakan Alternatif Lokasi Pelabuhan}

Berdasarkan kriteria dan indikator penilaian yang sudah disampaikan di atas, dilakukan proses pembobotan sesuai dengan skor rencana lokasi pelabuhan sebagaimana sudah dilakukan di bab analisis yang telah dilakukan sebelumnya. Proses pembobotan dilakukan dengan mengalikan nilai bobot sub aspek dengan nilai atau skor sub aspek tersebut di tiap rencana lokasi pelabuhan. Hasil pembobotan selengkapnya disajikan pada tabel berikut ini. 
Tabel 11. Perbandingan Kondisi Rencana Lokasi Pelabuhan Berdasarkan Keseluruhan Aspek

\begin{tabular}{|c|c|c|c|c|}
\hline No & Aspek & Sub Aspek & $\begin{array}{c}\text { Rencana Lokasi Pelabuhan Prigi } \\
\text { (Karanggongso) }\end{array}$ & Rencana Lokasi Pelabuhan Prigi (Cangkrong) \\
\hline \multirow[t]{2}{*}{1} & \multirow[t]{2}{*}{ Tata Ruang dan Kebijakan } & Struktur Ruang & $\begin{array}{l}\text { Rencana lokasi tercantum dalam RTRWP dan } \\
\text { RTRW Kab. }\end{array}$ & $\begin{array}{l}\text { Rencana lokasi tercantum dalam RTRWP dan } \\
\text { RTRW Kab. }\end{array}$ \\
\hline & & Kawasan Strategis & $\begin{array}{l}\text { Berada dekat dengan pengembangan Kawasan } \\
\text { Strategis Provinsi }\end{array}$ & $\begin{array}{l}\text { Berada dekat dengan pengembangan Kawasan } \\
\text { Strategis Provinsi }\end{array}$ \\
\hline \multirow[t]{4}{*}{2} & \multirow[t]{4}{*}{ Transportasi Wilayah } & Aksesibilitas Darat & $\begin{array}{l}\text { Nilai aksesibilitas sangat tinggi, didukung } \\
\text { dengan keberadaan JLS serta lanjutan } \\
\text { pembangunan JLS }\end{array}$ & $\begin{array}{l}\text { Nilai aksesibilitas sangat tinggi, didukung dengan } \\
\text { keberadaan JLS serta lanjutan pembangunan JLS }\end{array}$ \\
\hline & & Aksesibilitas Laut & $\begin{array}{l}\text { Belum dilayani angkutan laut, namun kondisi } \\
\text { alur pelayarana cukup mendukung }\end{array}$ & $\begin{array}{l}\text { Belum dilayani angkutan laut, namun kondisi alur } \\
\text { pelayarana cukup mendukung }\end{array}$ \\
\hline & & $\begin{array}{l}\text { Bangkitan dan tarikan } \\
\text { Pergerakan }\end{array}$ & $\begin{array}{l}\text { Jumlah bangkitan dan tarikan cukup tinggi } \\
\text { mengingat lokasi terletak pada kawasan strategis } \\
\text { pariwisata }\end{array}$ & $\begin{array}{l}\text { Jumlah bangkitan dan tarikan cukup tinggi } \\
\text { mengingat lokasi terletak pada kawasan strategis } \\
\text { pariwisata }\end{array}$ \\
\hline & & Sebaran Pergerakan & $\begin{array}{l}\text { Berada pada zona sebaran pergerakan yang } \\
\text { sedang }\end{array}$ & $\begin{array}{l}\text { Berada pada zona sebaran pergerakan yang } \\
\text { sedang }\end{array}$ \\
\hline \multirow[t]{2}{*}{3} & \multirow[t]{2}{*}{ Ekonomi Wilayah } & Potensi Komoditas Hinterland & $\begin{array}{l}\text { Memiliki beberapa komoditas unggulan serta } \\
\text { potensi ekspor }\end{array}$ & $\begin{array}{l}\text { Memiliki beberapa komoditas unggulan serta } \\
\text { potensi ekspor }\end{array}$ \\
\hline & & Indeks Pertumbuhan Wilayah & $\begin{array}{l}\text { Lokasi pelabuhan berada pada daerah sedang } \\
\text { tumbuh }\end{array}$ & $\begin{array}{l}\text { Lokasi pelabuhan berada pada daerah sedang } \\
\text { tumbuh }\end{array}$ \\
\hline \multirow[t]{2}{*}{4} & \multirow[t]{2}{*}{ Sosial Kependudukan } & Jumlah Penduduk & $\begin{array}{l}\text { Lokasi pelabuhan berada pada wilayah yang } \\
\text { jumlah penduduknya tergolong tinggi }\end{array}$ & $\begin{array}{l}\text { Lokasi pelabuhan berada pada wilayah yang } \\
\text { jumlah penduduknya tergolong tinggi }\end{array}$ \\
\hline & & Kepadatan penduduk & $\begin{array}{l}\text { Lokasi pelabuhan berada pada wilayah yang } \\
\text { kepadatan penduduknya tergolong tinggi }\end{array}$ & $\begin{array}{l}\text { Lokasi pelabuhan berada pada wilayah yang } \\
\text { kepadatan penduduknya tergolong tinggi }\end{array}$ \\
\hline \multirow[t]{2}{*}{5} & \multirow[t]{2}{*}{ Lingkungan } & Komponen Fisik-Kimia & $\begin{array}{l}\text { Penggunaan lahan kawasan daratan berupa } \\
\text { kawasan semak belukar, dan terdapat beberapa } \\
\text { pohon kelapa, termasuk kawasan hutan produksi }\end{array}$ & $\begin{array}{l}\text { Penggunaan lahan kawasan daratan berupa } \\
\text { kawasan semak belukar, dan terdapat beberapa } \\
\text { pohon kelapa, termasuk kawasan hutan produksi }\end{array}$ \\
\hline & & Komponen Biologi-Hayati & $\begin{array}{l}\text { Tidak terdapat karang pada wilayah perairan. } \\
\text { Namun masuk pada wilayah tangkapan ikan PPN } \\
\text { Prigi }\end{array}$ & $\begin{array}{l}\text { Tidak terdapat karang pada wilayah perairan. } \\
\text { Namun masuk pada wilayah tangkapan ikan PPN } \\
\text { Prigi }\end{array}$ \\
\hline
\end{tabular}




\begin{tabular}{|c|c|c|c|c|}
\hline No & Aspek & Sub Aspek & $\begin{array}{c}\text { Rencana Lokasi Pelabuhan Prigi } \\
\text { (Karanggongso) }\end{array}$ & Rencana Lokasi Pelabuhan Prigi (Cangkrong) \\
\hline & & Rawan Bencana & $\begin{array}{l}\text { Berada pada zona rawan bencana gerakan tanah } \\
\text { longsor (kondisi tanah labil) dan tsunami, tidak } \\
\text { berada pada wilayah rawan banjir }\end{array}$ & $\begin{array}{l}\text { Berada pada zona rawan bencana gerakan tanah } \\
\text { longsor (kondisi tanah labil) dan tsunami, tidak } \\
\text { berada pada wilayah rawan banjir }\end{array}$ \\
\hline \multirow[t]{5}{*}{6} & \multirow[t]{5}{*}{ Teknis } & Topografi dan Kelerengan & $\begin{array}{l}\text { umumnya berkontur rendah dan datar. } \\
\text { Kemiringan lahan sekitar } 0,20 \% \text {. Perbedaan } \\
\text { ketinggian antara } 0-3 \mathrm{~m} \text { di atas permukaan laut }\end{array}$ & $\begin{array}{l}\text { umumnya berkontur rendah dan datar. } \\
\text { Kemiringan lahan sekitar } 0,20 \% \text {. Perbedaan } \\
\text { ketinggian antara } 0-3 \mathrm{~m} \text { di atas permukaan laut }\end{array}$ \\
\hline & & Bathymetri & $\begin{array}{l}\text { Kondisi Batimetri cukup ideal, berdasarkan peta } \\
\text { batimetri untuk } \\
\text { mencapai kedalaman }-10 \text { m membutuhkan jarak } \\
145 \text { m dari garis } \\
\text { pantai. }\end{array}$ & $\begin{array}{l}\text { Kondisi Batimetri cukup ideal, } \\
\text { berdasarkan peta batimetri untuk } \\
\text { mencapai kedalaman }-10 \mathrm{~m} \\
\text { membutuhkan jarak } 600 \mathrm{~m} \text { dari garis } \\
\text { pantai. }\end{array}$ \\
\hline & & Hidrooaseanografi & $\begin{array}{l}\text { Tinggi gelombang rata-rata berkisar antara } 0.4- \\
0.7 \text { m sehingga aman untuk didarati kapal ketika } \\
\text { sandar }\end{array}$ & $\begin{array}{l}\text { Tinggi gelombang berpotensi lebih dari } 1 \text { meter } \\
\text { sehingga membahayakan kapal jika sedang sandar } \\
\text { di pelabuhan }\end{array}$ \\
\hline & & Klimatologi & $\begin{array}{l}\text { Kondisi angin dominan dari arah timur dan } \\
\text { dengan wilayah teluk yang cukup terlindungi. } \\
\text { Merupakan kawasan yang tidak dipengaruhi } \\
\text { angin musim (operasional pelabuhan } \\
\text { tidak terganggu sepanjang tahun) }\end{array}$ & $\begin{array}{l}\text { Kondisi angin dominan dari arah timur, wilayah } \\
\text { Cangkrong cukup terbuka. Wilayah termasuk } \\
\text { kawasan dengan pengaruh angin musim yang } \\
\text { (berpotensi mengganggu operasional } \\
\text { pelabuhan) }\end{array}$ \\
\hline & & Status Lahan & Lahan Rencana lokasi pelabuhan milik perhutani. & Lahan Rencana lokasi pelabuhan milik perhutani. \\
\hline
\end{tabular}


Tabel 12. Penilaian Rencana Lokasi Pelabuhan Berdasarkan Keseluruhan Aspek

\begin{tabular}{|c|c|c|c|c|c|c|c|c|}
\hline \multirow{2}{*}{ No } & \multirow{2}{*}{ Aspek } & \multirow{2}{*}{ Sub Aspek } & \multirow{2}{*}{$\begin{array}{c}\text { Sub Sub } \\
\text { Aspek }\end{array}$} & \multirow{2}{*}{ Bobot } & \multicolumn{2}{|c|}{ Prigi (Karanggongso) } & \multicolumn{2}{|c|}{ Prigi (Cangkrong) } \\
\hline & & & & & Skor & $\begin{array}{l}\text { Bobot x } \\
\text { Skor }\end{array}$ & Skor & $\begin{array}{l}\text { Bobot x } \\
\text { Skor }\end{array}$ \\
\hline \multirow[t]{3}{*}{1} & \multirow{3}{*}{$\begin{array}{l}\text { Aspek } \\
\text { Kebijakan dan } \\
\text { Tata Ruang }\end{array}$} & Pola Ruang & & $5 \%$ & 5 & 0.25 & 5 & 0.25 \\
\hline & & Struktur Ruang & & $5 \%$ & 6 & 0.3 & 6 & 0.3 \\
\hline & & Kawasan Strategis & & $5 \%$ & 6 & 0.3 & 6 & 0.3 \\
\hline \multirow[t]{5}{*}{2} & \multirow{5}{*}{$\begin{array}{l}\text { Aspek Sosial } \\
\text { Ekonomi dan } \\
\text { Kependudukan }\end{array}$} & \multirow{2}{*}{$\begin{array}{l}\text { Potensi } \\
\text { Komoditas } \\
\text { Hinterland }\end{array}$} & $\begin{array}{l}\text { Location } \\
\text { Quotient (LQ) }\end{array}$ & $7 \%$ & 10 & 0.7 & 10 & 0.7 \\
\hline & & & Growth-Share & $7 \%$ & 1 & 0.07 & 1 & 0.07 \\
\hline & & $\begin{array}{l}\text { Pertumbuhan } \\
\text { Wilayah }\end{array}$ & & $4 \%$ & 5 & 0.2 & 5 & 0.2 \\
\hline & & \multirow[t]{2}{*}{ Penduduk } & $\begin{array}{l}\text { Jumlah } \\
\text { Penduduk }\end{array}$ & $5 \%$ & 10 & 0.5 & 10 & 0.5 \\
\hline & & & $\begin{array}{l}\text { Kepadatan } \\
\text { Penduduk }\end{array}$ & $5 \%$ & 10 & 0.5 & 10 & 0.5 \\
\hline \multirow[t]{8}{*}{3} & \multirow{8}{*}{$\begin{array}{l}\text { Aspek } \\
\text { Transportasi } \\
\text { Wilayah }\end{array}$} & \multirow[t]{3}{*}{$\begin{array}{l}\text { Aksesibilitas } \\
\text { Darat }\end{array}$} & $\begin{array}{l}\text { Aksesibilitas } \\
\text { Ekternal }\end{array}$ & $4 \%$ & 10 & 0.4 & 10 & 0.4 \\
\hline & & & $\begin{array}{l}\text { Aksesibilitas } \\
\text { Internal }\end{array}$ & $3 \%$ & 10 & 0.3 & 10 & 0.3 \\
\hline & & & $\begin{array}{l}\text { Aksesibilitas } \\
\text { menuju } \\
\text { pelabuhan } \\
\text { eksisting } \\
\text { sekitar }\end{array}$ & $3 \%$ & 10 & 0.3 & 10 & 0.3 \\
\hline & & \multirow[t]{3}{*}{ Aksesibilitas Laut } & $\begin{array}{l}\text { Kondisi } \\
\text { pelayanan } \\
\text { angkutan laut } \\
\end{array}$ & $4 \%$ & 2.8 & 0.11 & 2.8 & 0.11 \\
\hline & & & $\begin{array}{l}\text { kondisi } \\
\text { pelayanan } \\
\text { kepelabuhanan } \\
\text { eksisting } \\
\text { sekitar }\end{array}$ & $3 \%$ & 10 & 0.3 & 10 & 0.3 \\
\hline & & & Alur Pelayaran & $3 \%$ & 10 & 0.3 & 10 & 0.3 \\
\hline & & $\begin{array}{l}\text { Bangkitan dan } \\
\text { Tarikan } \\
\text { Pergerakan } \\
\end{array}$ & & $5 \%$ & 3 & 0.15 & 3 & 0.15 \\
\hline & & $\begin{array}{l}\text { Sebaran } \\
\text { Pergerakan }\end{array}$ & & $5 \%$ & 3 & 0.15 & 3 & 0.15 \\
\hline \multirow[t]{5}{*}{4} & \multirow[t]{5}{*}{ Aspek Teknis } & $\begin{array}{l}\text { Topografi dan } \\
\text { Kelerengan }\end{array}$ & & $5 \%$ & 10 & 0.5 & 10 & 0.5 \\
\hline & & Bathymetri & & $5 \%$ & 10 & 0.5 & 5 & 0.25 \\
\hline & & Hidrooaseanografi & & $4 \%$ & 10 & 0.4 & 1 & 0.04 \\
\hline & & Klimatologi & & $4 \%$ & 10 & 0.4 & 5 & 0.2 \\
\hline & & Status Lahan & & $4 \%$ & 4 & 0.16 & 4 & 0.16 \\
\hline 5 & $\begin{array}{l}\text { Aspek } \\
\text { Lingkungan }\end{array}$ & $\begin{array}{l}\text { Komponen } \\
\text { Lingkungan } \\
\text { Hidup } \\
\end{array}$ & & $5 \%$ & 5 & 0.25 & 5 & 0.25 \\
\hline \multicolumn{4}{|c|}{ JUMLAH } & $100 \%$ & & 7.04 & & 6.23 \\
\hline
\end{tabular}

\section{KESIMPULAN}

1. Dari analisis awal yang menyeleksi rencana lokasi pelabuhan dari long list ke short list, diperoleh 2 lokasi rencana pelabuhan (short list) yang terletak di Teluk Prigi yaitu Karanggongso \& Cangkrong. Kedua lokasi tersebut berada di Kec. Watulimo, Kab. Trenggalek.

2. Dari hasil analisis mendalam tiap alternatif rencana lokasi yang meliputi analisis tata ruang, transportasi, ekonomi, sosial kependudukan, rona lingkungan, dan analisis teknis, 
terpilih lokasi Prigi (Karanggongso) sebagai lokasi yang memiliki prioritas tertinggi dengan skor 7,04.

3. Dari analisis yang sudah dilakukan, cukup sulit untuk mendapatkan kesimpulan bulat bahwa terdapat indikasi kelayakan pembangunan pelabuhan di Kabupaten Trenggalek. Hal ini disebabkan beberapa hal antara lain :

a. Meskipun kondisi perairan di lokasi pelabuhan cukup tenang karena terlindung, kondisi alur pelayaran di laut selatan pulau jawa memiliki gelombang yang tinggi terutama pada bulan-bulan tertentu sehingga kapal akan sangat sulit untuk berlayar secara reguler. Kondisi ini juga yang menyebabkan masih sedikit rute pelayaran yang melalui laut selatan pulau jawa.

b. Wilayah foreland di selatan jawa relatif terbatas. Dalam jangka pendek, mungkin hanya wilayah pulau bali yang berpotensi sebagai wilayah foreland. Sedangkan wilayah jawa karena kondisi jalan yang sudah cukup baik baik di jalur utara maupun selatan, maka kemungkinan moda laut akan kalah bersaing dengan moda darat, karena sangat sedikit pelabuhan di selatan jawa.

c. Komoditas-komoditas potensial di wilayah hinterland seperti gula, bambu, produk marmer, dan hasil industri kimia, umumnya diekspor ke luar negeri atau pun dikirim ke daerah lain melalui Pelabuhan Tanjung Perak yang sudah memiliki fasilitas yang sangat memadai, sehingga meskipun secara akses lebih dekat ke Pelabuhan Prigi, para eksportir cenderung akan memilih Pelabuhan Tanjung Perak.

d. Kondisi akses jalan eksisting menuju rencana lokasi Pelabuhan Prigi, melalui kawasan topografi perbukitan yang cukup terjal. Kondisi ini menjadi tantangan bagi truk angkutan barang yang akan mengangkut barang dari pelabuhan ke kawasan hinterland dan sebaliknya.

\section{DAFTAR PUSTAKA}

Fisu AA. (2016). “Analisis dan Konsep Perencanaan Kawasan Pelabuhan Kota Penajam sebagai Pintu Gerbang kab. Penajam Paser Utara, Kalimantan Timur”. Jurnal Pena Teknik Vol.01 No.02 September 2016. 125-136.

Fisu AA. (2018). "Analisis Kebutuhan Fasilitas Sisi Laut Pelabuhan Terminal Khusus PLTGU Lombok". Jurnal Pena Teknik Vol.03 No.02 2018. 197-206

Fisu AA. (2018). “Analisis Lokasi Pada Perencanaan Terminal Topoyo, Mamuju Tengah”. Jurnal Pena Teknik Vol.02 No.01 2018

Fisu AA. (2016). "Potensi Demand pengembangan Kanal Jongaya \& Panampu Sebagai Moda Transportasi Kota Makassar". Jurnal JMTranslog Trisakti Vol 03 no 03, Jakarta.

Fisu AA. (2019). Analisis Kelayakan Ekonomi \& Finansial pada Masterplan Kawasan Industri Perikanan Kota Tarakan. https://doi.org/10.31227/osf.io/96yzu.

Fisu AA. (2019). “Tinjauan TransportasiPada Kawasan Komersil (Studi Kasus Jalan Cihampelas Kota Bandung)". https://doi.org/10.31227/osf.io/s9u2a

Humang Windra Priatna \& Zulfadly, (2016), "Analisis Keterpaduan Moda Transportasi Angkutan Penyeberangan Dengan Jalan Raya di Pelabuhan Bajoe Kab. Bone”, Jurnal Pena Teknik Universitas Andi Djemma, Palopo

Natsir Rakhmawati. 2016. "Karakteristik Kinerja Moda Angkutan Umum Kota Palopo (Studi Kasus Penumpang Bus Executive, Suspensi Udara, Scania - PO Bintang Prima". Jurnal Pena Teknik Universitas Andi Djemma, Palopo. 